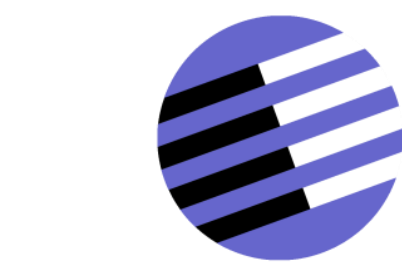

GOVERNANCE AND THE EFFICIENCY

OF ECONOMIC SYSTEMS

G E S Y

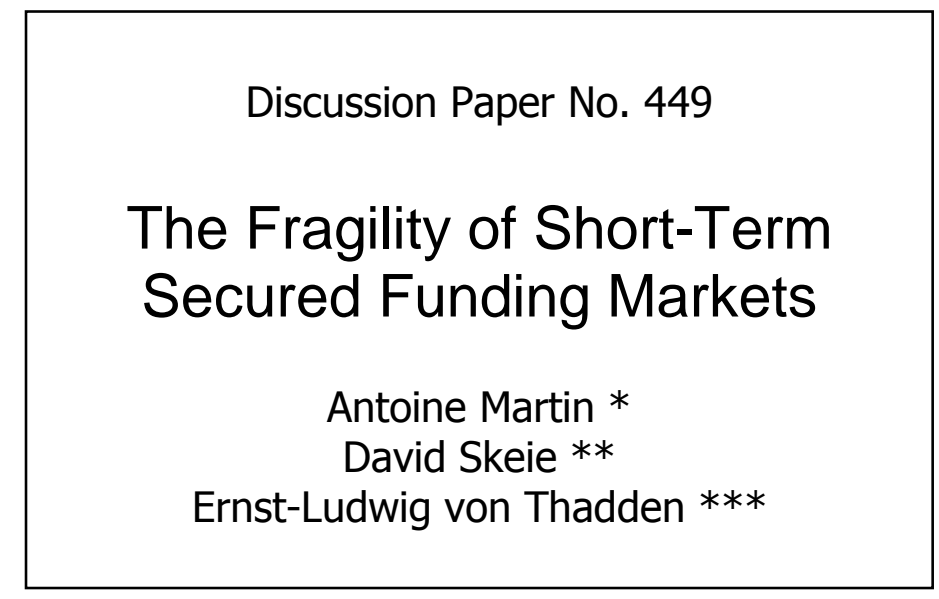

* / ** Federal Reserve Bank of New York

*** Universität Mannheim

Financial support from the Deutsche Forschungsgemeinschaft through SFB/TR 15 is gratefully acknowledged. 


\title{
The Fragility of Short-Term Secured Funding Markets
}

\author{
Antoine Martin David Skeie \\ Ernst-Ludwig von Thadden ${ }^{1}$ \\ Journal of Economic Theory, 2014
}

\begin{abstract}
This paper develops an infinite-horizon model of financial institutions that borrow short-term and invest in long-term assets that can be traded in frictionless markets. Because these financial intermediaries perform maturity transformation, they are subject to potential runs. We derive distinct liquidity, collateral, and asset liquidation constraints, which determine whether a run can occur as a result of changing market expectations. We show that the extent to which borrowers can ward off an individual run depends on whether it has sufficient liquidity, collateral, and asset liquidation capacity. These determinants depend on the borrower's (endogenous) balance sheet and on (exogenous) fundamentals. Systemic runs are possible if shocks to the valuation of collateral held by outside investors are sufficiently strong and uniform, and if the system as a whole is exposed to high short-term funding risk. The theory has policy implications for prudential regulation and lender-of-last-resort interventions.
\end{abstract}

Keywords: Investment banking, securities dealers, repurchase agreements, runs, financial fragility, collateral, systemic risk.

JEL classification: E44, E58, G24

\footnotetext{
${ }^{1}$ Martin and Skeie are at the Federal Reserve Bank of New York. Von Thadden is at the University of Mannheim. Author e-mails are antoine.martin@ny.frb.org, david.skeie@ny.frb.org, and vthadden@uni-mannheim.de, respectively. We thank Viral Acharya, Sudipto Bhattacharya, Amar Bhide, Patrick Bolton, Douglas Gale, Gary Gorton, Yaron Leitner, Ed Nosal, Lasse Pedersen, Matt Pritzker, Bogdan Stacescu, Dimitri Vayanos, an anonymous referee, as well as the participants of the Gerzensee Summer Symposium 2011, for helpful comments, and Ali Palida for very good research assistance. Part of this research was done while von Thadden was at the Finance Department of the London School of Economics. The views expressed in this paper are those of the authors and do not necessarily reflect the views of the Federal Reserve Bank of New York or the Federal Reserve System.
} 


\section{Introduction}

This paper develops a model of financial institutions funded by short-term borrowing and investing in long-term marketable assets. We show that such institutions are subject to the threat of runs similar to those faced by commercial banks and study the conditions under which runs can occur. The analysis derives liquidity, collateral, and asset liquidation constraints for such institutions that depend on whether the run is on an individual institution only or is systemic. When these constraints are violated, runs can occur.

Institutions threatened by a run can liquidate assets through market sales to raise cash or increase the collateral they offer to attract emergency lending. For both these reactions, the institution's asset base compared to its borrowing exposure is decisive. In our steady-state model, these two key variables are endogenous, but not pinned down uniquely. The ability to survive a run depends on these two variables, as well as on exogenous parameters such as the institution's profitability and size.

Our work builds on the theory of commercial bank instability developed by Diamond and Dybvig (1983), Qi (1994), and others. As pointed out by Gorton and Metrick (2012), there are important similarities between the fragility of commercial banks that borrow unsecured deposits and hold nonmarketable loan portfolios, and of "securitized" or "shadow" banks, which borrow in repo or other short-term funding markets against marketable securities as collateral. ${ }^{2}$ In particular, repo markets perform maturity transformation by allowing investors with uncertain liquidity needs to lend short-term against longer term, less liquid securities. We provide a formal model of shadow banking to identify the determinants of equilibrium profits, liquidity, collateral, and asset market prices that support such maturity transformation during normal times, and examine its fragility.

This paper uses the model developed in Martin, Skeie, and von Thadden (2014), which focuses on the market microstructure of short-term funding markets and compares the impact of different market structures on the possibility of runs, but ignores asset markets. The present paper simplifies the

\footnotetext{
${ }^{2}$ See Pozsar, Adrian, Ashcraft, and Boesky (2010) for a detailed discussion of the role of shadow banking in the recent financial crisis.
} 
microstructure, but introduces asset market activity and analyzes its impact on market fragility. The interdependency between the asset side and liability side of a borrower's balance sheet determines the borrower's fragility and in aggregate determines market fragility.

In contrast to Diamond and Dybvig (1983), we study an infinite-horizon model. A key benefit is that profits are endogenous, so that we can make predictions about how the model's structural parameters affect the stability of the steady state via the endogenously generated liquidity, rather than performing comparative statics with respect to exogenous liquidity levels. Qi (1994) also considers an infinite-horizon model, but his financial institutions are assumed to make zero profits. ${ }^{3}$ In fact, we show that competition does not necessarily drive up interest rates to zero-profit levels in equilibrium, because borrowers with liquidity of their own must have an incentive to borrow rather than using their own funds for investment. Since investing own funds is profitable, so must be borrowing. This equilibrium argument for positive profits has been developed in Martin, Skeie, and von Thadden (2014) and relies on a tradeoff between the use of external and internal funds, which are endogenous in our infinite-horizon model, but would need to be exogenously specified in a static model.

A further key difference to Diamond-Dybvig (1983) is the existence of asset markets in our model. This is a feature that our model shares with Diamond (1997), who introduces an asset market with limited participation into the Diamond-Dybvig model and shows that banking coexists with market activity in equilibrium and shows how both types of activities influence each other. In our model, as in several others, ${ }^{4}$ asset market participation is restricted to sophisticated borrowers (the "banks" in the Diamond-Dybvig world), which rules out the type of coexistence problem studied by Diamond (1997). Differently from that paper, our focus is on the role of asset markets in runs.

In this respect our work is similar to the small literature, led by Allen and

\footnotetext{
${ }^{3}$ Other recent infinite-horizon models of banking instability such as He and Xiong (2012) or Segura and Suarez (2012) also generate positive equilibrium profits, but do not consider their interaction with asset markets and fire sales, which is the focus of the present paper.

${ }^{4}$ Such as Acharya, Shin, and Yorulmazer (2011) or Allen and Gale (2004a).
} 
Gale (2004a, 2004b), that introduces Walrasian markets into the DiamondDybvig model. ${ }^{5}$ Allen and Gale $(2004 \mathrm{a}, 2004 \mathrm{~b})$ note that the liquidity obtained from asset markets (or equivalently, perfect future markets for statecontingent consumption) complements that obtained through intermediaries and study its limits because of insufficient cash in the market or market incompleteness. Differently from that literature, we consider the use of assets as collateral to support borrowing. Much of our analysis is concerned with expectation-based runs on individual borrowers, and our question is to what extent asset markets can overcome such breakdowns of short-term borrowing markets. A well-functioning asset market makes it possible for a distressed borrower to sell assets and thus obtain emergency liquidity. However, the existence of these markets also in good times makes it possible for borrowers to bring consumption forward in time. This type of activity corresponds to securitization: the steady-state sale of assets by a financial institution that could otherwise be kept on balance sheet, motivated by the desire to generate cash before the assets mature. ${ }^{6}$ An important result of our paper is that securitization (net asset sales) weakens a borrower's balance sheet because it reduces the assets available to raise cash in case of emergency, either through liquidation or additional collateral. The model therefore predicts that borrowers that securitize less will be less fragile.

This view on securitization resembles Parlour and Plantin's (2007) argument that liquid asset markets may not be socially optimal, because they facilitate securitization without providing incentives to monitor the quality of the assets sold. In our model, liquid asset markets are beneficial because they can provide liquidity when individual borrowers are under stress, but they can create fragility if their use erodes the borrower's asset base too much.

The liquidity of a borrower's balance sheet plays a key role in our model

\footnotetext{
${ }^{5}$ An excellent introduction into this literature is the broad survey by Allen and Gale (2007).

${ }^{6}$ Securitization typically involves both the pooling and tranching of assets and the sale of the resulting securities. In this paper, we focus on the latter, which has been a major factor in the financial crisis of 2007, as argued forcefully by Acharya, Schnabl, and Suarez (2013). We abstract from issues such as pooling and tranching (see DeMarzo, 2005, Martin and Parigi, 2013) and consider only homogenous assets.
} 
as we derive a kind of "pecking order" of means by which borrowers can react to an attempted run. First, borrowers can use equilibrium free cash flow and investment (inside liquidity in the terminology of Bolton, Santos and Scheinkman (2011)) as a buffer. If these are insufficient, they can reduce borrowing levels and attract some emergency lending by posting more collateral. If the run is on a single borrower only and if the borrower cannot raise enough outside liquidity through higher collateralization, the borrower can sell his assets in a final attempt to generate liquidity. How much asset sales can help, however, depends on various factors, including the strength of the borrower's balance sheet and the market price of assets. Importantly, with a well-functioning asset market, borrowers can make themselves run-proof by a judicious choice of balance sheet structure. In Section 4, we characterize these structures explicitly.

Healthy borrows are willing to pay for the assets of distressed borrowers up to the opportunity cost of their funds. As more assets are sold, the price of assets declines, and it becomes more difficult for a distressed borrower to raise cash. The more borrowers simultaneously are in distress and attempt to sell their assets at the same time, the more difficult does this become because of the limited cash in the market (Allen and Gale, 1994). In Section 5 , we focus on the extreme case of a market-wide run, where the asset market collapses completely because no borrower is available to buy assets.

Because liquidity is seriously impaired in a systemic crisis, it turns out that at the systemic level collateral is decisive for the survival of borrowers. We show that if shocks to the asset values of all borrowers are sufficiently strong and correlated, a run on all borrowers is possible as a self-fulfilling expectation. In this case, ex post liquidity interventions by the lender of last resort are required to prevent complete market collapse. Ex ante, this can be avoided by the appropriate regulation of borrowers' balance sheets in terms of asset market exposure and short-term borrowing. In Section 6, we discuss the regulatory consequences of our analysis in the context of the current policy debate.

It is instructive to compare our results on endogenous liquidity to those of the finite-horizon literature on banking fragility and asset markets in which either a form of "inside" or "outside" liquidity is exogenously given in a 
starting period.

The importance of inside liquidity in financial stress has recently been emphasized by Bolton, Santos and Scheinkman (2011), who show that inside liquidity can be an inefficient source of paying off short-term claims because this reduces the amount of a bank's balance sheet that can be used for productive purposes. This inefficiency exists also in our model. Yet, in our infinite-horizon framework the composition of a borrower's balance sheet and hence her "inside liquidity" available to pay out at short notice is endogenous, and it comprises free cash flow that can be shifted from consumption to repayment at no efficiency loss.

Allen and Gale (1998) discuss fire sales of assets in a setting with exogenous outside liquidity. As in that paper, in our systemic run scenario, low enough collateral values imply a fire-sale collapse of asset prices below fundamental value, which cannot be prevented by the endogenous amount of cash in the market. Allen and Gale (1998) assume an exogenous amount of outside speculators' wealth, which, if large enough, will prevent extreme asset price drops. A lack of asset markets in which speculators can buy fire sale assets implies fewer runs because the depositors cannot receive any value on assets directly - in effect, the collateral value that can be received by depositors in a run is always zero.

Fecht (2004) extends Diamond (1997) to examine how the degree of household segmentation to direct investment opportunities can lead to either a banking-dominated financial system or an asset-market dominated system. He shows that contagion from an individual bank run does not occur in either a banking system or market system, but can occur in a hybrid mix of banking and markets because of a contagious dry-up of liquidity. We extend this analysis by arguing that contagion can be an important systemic phenomenon, but show that functioning asset markets can provide support to individual financial intermediaries threatened by a run by reallocating liquidity when the bank is forced to sell off assets.

Gorton and Huang (2004) argue that a liquid asset market requires banks to rely on their long-term assets to provide full liquidity as a buffer against the threat of a run, which imposes an inefficiency in a static model. However, we show that with an infinite-horizon, financial intermediaries have a buffer 
of liquidity in addition to their long term assets because they naturally have a constant source of new liquidity - new lenders in each period and the adjustment of investment to draw forward liquidity from future profits, which are both inherently sources of cash.

\section{The Model}

The model is a simplified version of Martin, Skeie and von Thadden (2014), augmented by asset markets. The economy lasts forever and does not have an initial date. At each date $t$, a continuum of mass $N$ of "young" investors is born. Investors live for three dates and are born with an endowment of 1 unit of a single good ("money"). They have no endowment thereafter. Investors' preferences for the timing of consumption are unknown when born at date $t$. At date $t+1$, investors learn their type. "Impatient" investors need cash at date $t+1$, while "patient" investors do not need cash until date $t+2$. The information about the investors' type and age is private, i.e., cannot be observed by the market. Ex ante, the probability of being impatient is $\alpha$. We assume that the fraction of impatient agents in each generation is also $\alpha$ (the Law of Large Numbers).

The timing of the investors' needs of cash is uncertain because of "liquidity" shocks. In practice, money market investors, such as MMMFs, may learn about longer term investment opportunities and wish to redeploy their cash or they may need to generate cash to satisfy sudden outflows from their own investors. We model this preference for liquidity as Diamond and Dybvig (1983) by assuming that the utility from consuming $\left(c_{1}, c_{2}\right)$ over the two-period horizon is given by

$$
U\left(c_{1}, c_{2}\right)= \begin{cases}u_{1}\left(c_{1}\right) & \text { with prob. } \alpha \\ u_{2}\left(c_{2}\right) & \text { with prob. } 1-\alpha\end{cases}
$$

with $u_{1}$ and $u_{2}$ strictly increasing. ${ }^{7}$

\footnotetext{
${ }^{7}$ We do not require the traditional consumption-smoothing motive of the DiamondDybvig literature (concave $u_{t}$ ) here. Financial investors as modelled here may well be risk-averse, but this assumption is not necessary for our analysis. In order to prove that optimal contracts are one-period (which we assume here right away) one needs further
} 
Everybody in the economy has access to a one-period storage technology, which can be thought of as cash saving and returns 1 for each unit invested.

The economy is also populated by $M \geq 3$ infinitely-lived risk-neutral agents called borrowers and indexed by $i \in\{1, \ldots, M\} .{ }^{8}$ Borrowers maximize the sum of discounted expected future consumption, where the discount factor is $\beta<1$. They represent, for example, securities dealers or hedge funds. Borrowers have access to an investment technology, which we think of as investment in, and possibly the creation of, securities. These investments pay off only after some delay, but they can be sold on a perfect asset market that we describe below. The investments are subject to decreasing returns, which we model simply by assuming that there is a limit beyond which the investment provides no returns. Hence, investing $I^{t}$ units at date $t$ yields

$$
\begin{cases}R_{i} I^{t} & \text { if } I^{t}<\overline{I_{i}} \\ R_{i} \overline{I_{i}} & \text { if } I^{t} \geq \overline{I_{i}}\end{cases}
$$

with $R_{i}>1$ at date $t+2$ for all $t$ and yields nothing at date $t+1$. To simplify the analysis, we assume that the return on these investments is riskless. In order to have a role for collateral in our model, we assume that the return is not verifiable. This means that investors cannot be sure that a borrower has indeed realized $R_{i} I^{t}$ from his past investment. Although this is a probability zero event, a borrower who has received funds from investors can claim that he cannot repay the investors.

In order to make the problem interesting, we assume that borrowers are sufficiently patient and their long-term investment is sufficiently profitable:

$$
\beta^{2} R_{i}>1
$$

for all $i$. Without assumption (3), borrowers would prefer to consume liquid funds immediately rather than invest.

Investment returns can only be realized by borrowers because they have a comparative advantage in managing security portfolios. Investors could

assumptions. Strict concavity can be used, but is not the only possible assumption (see Martin, Skeie, von Thadden, 2014).

${ }^{8}$ We exclude the case $M=2$ in order to avoid trivial monopolization problems if one borrower does not participate in asset markets. 
realize a smaller return of $\gamma_{i}^{t} R_{i}$ from these assets, with $\gamma_{i}^{t}<1$ for all $t$. $\gamma_{i}^{t}$ reflects different skills in valuing or managing the assets, possible restrictions on investors' portfolio composition, transactions and timing costs, and similar asymmetries. ${ }^{9}$ We allow $\gamma_{i}^{t}$ to depend on the borrower, reflecting potential differences in the portfolio of collateral that different borrowers seek to finance, and allow it to depend on $t$ since the outside value of such portfolios may change over time.

Borrowers can use investor funds to invest in securities. To make the model interesting, we must assume that each period the total investment capacity $\sum \overline{I_{i}}$ strictly exceeds the investors' cash available for investment, $N$. Without this assumption, there would be no competition among borrowers for investor funds. Borrowers could extract all the surplus from investors by simply offering to pay the storage return of 1 each period, and there would be no instabilities or runs. To simplify the analysis, we assume the slightly stronger condition that no single borrower is pivotal:

$$
\sum_{j \neq i} \overline{I_{j}}>N
$$

for all $i$.

These investments are liquid in the sense that there exist competitive markets for the resulting assets. At each date $t$, borrower $i$ has $I_{i}^{t-1}$ in existing investments that will yield $R_{i} I_{i}^{t-1}$ in $t+1$. These assets can be sold to other borrowers ("securitized") at the price $p_{i}^{t}$. We assume that this market is frictionless, so that a borrower $j \neq i$ who buys the amount $0 \leq A_{j i}^{t} \leq I_{i}^{t-1}$ from borrower $i$ will realize $R_{i} A_{j i}^{t}$ in $t+1 .{ }^{10}$ Conversely, if borrower $i$ sells the amount $A_{i}^{t}$ of assets this yields $p_{i}^{t} A_{i}^{t}$ in cash. We have

$$
A_{i}^{t}=\sum_{j} A_{j i}^{t}
$$

\footnotetext{
${ }^{9}$ For T-bills, $\gamma_{i}^{t}$ should be very close to 1 most of the time. But borrowers typically also finance large volumes of less liquid securities.

${ }^{10}$ By considering frictionless secondary markets, we bias our results against runs and in favor of market stability (see Skeie 2008). For example, if we instead assumed that other borrowers could realize only $\widehat{\gamma}_{i}^{t} R_{i}<R_{i}$ from borrower $i$ 's assets, the analysis would be similar, but the conditions for no runs to be possible would be tighter. See Martin, Skeie and von Thadden (2014) or Acharya, Gale and Yorulmazer (2011) for such analyses.
} 
where we define $A_{i i}^{t}=0$.

To simplify the exposition, we assume that only borrowers have access to this market. ${ }^{11}$ There are $M$ such markets, one for each borrower's assets, ${ }^{12}$ and the market prices $p_{i}^{t}$ are determined as competitive equilibrium prices.

Each period, borrowers compete for investors' funds. Since borrowers have a fixed investment capacity, they cannot borrow unlimited amounts, but must condition their contract offers on the amount of funds they receive. We capture this conditionality by a limit $Q_{i}^{t}$, up to which the borrower wants to borrow at the terms indicated. Since investors live for two periods, contracts should in principle extend over two periods, and because of the liquidity shock, they should be callable on demand. In Martin, Skeie and von Thadden (2014) we show that any such long-term demand-type contract must in fact be a sequence of short-term contracts. ${ }^{13}$ Given this result, we simplify the analysis here by assuming that borrowers only offer one-period contracts. Such contracts promise to repay $r_{i}^{t}$ at date $t+1$ for each dollar borrowed at date $t$. Hence, if borrower $i$ attracts funds $b_{i}^{t}$ from young investors at date $t$, then he can expect to repay $\alpha r_{i}^{t} b_{i}^{t}$ at date $t+1$ and to roll over the remaining $(1-\alpha) r_{i}^{t} b_{i}^{t}$ for another period.

Furthermore, since investment returns are non-verifiable, borrowers must post collateral. The collateral posted must be sufficient to incentivize borrowers to repay or, if one interprets the borrowing as repo transactions, to honor the repurchase leg of the repo transaction. At the time $t$ of the contract offers, the borrower wants to roll over $(1-\alpha) r_{i}^{t-1} b_{i}^{t-1}$ in loans from patient middle-aged investors and attract $b_{i}^{t}$ from young investors. The borrower has

\footnotetext{
${ }^{11}$ The assumption that final investors cannot participate in the asset market does not affect the analysis of single-borrower runs, because borrowers are more efficient in using the assets and thus will be the only ones to trade. It simplifies the analysis of aggregate runs because, instead of shutting down, this market could then operate at low prices, depending on the collateral constraint (see Section 5).

${ }^{12}$ If we assume instead that all borrowers essentially operate the same assets, only differing in their skill (leading to different $R_{i}$ 's), our analysis of Sections 4 and 5 does not change. The analysis of partial runs, not considered in this paper, would change slightly.

${ }^{13}$ More precisely, optimal long-term callable contracts cannot do better than a sequence of simple short-term loans. If $r_{\tau i}$ are the $\tau$-period repayment promises with liquidation option, $\tau=1,2$, then $r_{2 i}=r_{1 i}^{2}$, where $r_{1 i}=r_{i}$ is the one-period gross interest rate. The reason for this result is that liquidity shocks are non-contractible.
} 
collateral of two kinds: $I_{i}^{t-1}$ units of assets created last period and maturing in $t+1$ ("seasoned collateral"), and $I_{i}^{t}$ units of assets created by this period's investment ("fresh collateral"). To simplify the presentation, we assume that borrowers collateralize all their loans by an equally weighted mix of the two types of collateral: if a loan of size 1 is collateralized at rate $k_{i}$, then the collateral is composed of $\frac{1}{2} k_{i}$ units of seasoned collateral and fresh collateral each. ${ }^{14}$

Hence, if the one-period gross interest rate is $r_{i}$, then the borrower will repay a loan (i.e., redeem his collateral) next period instead of keeping his cash, if the value of the collateral to the borrower next period is greater than the total repayment promise:

$$
\begin{aligned}
\frac{1}{2} k_{i} R_{i}+\frac{1}{2} k_{i} \beta R_{i} & \geq r_{i} \\
\Leftrightarrow \quad \frac{1}{2}(1+\beta) R_{i} k_{i} & \geq r_{i}
\end{aligned}
$$

We will abstract from more complicated considerations of default and ex post bargaining, and simply assume that collateral must satisfy the repayment constraint (5). ${ }^{15}$ To summarize, borrowing contracts are triples $\left(r_{i}^{t}, Q_{i}^{t}, k_{i}^{t}\right) \in \mathbb{R}_{+}^{3}, i=1, \ldots, M$, where $r_{i}^{t}$ is the repayment made by borrower $i$ next period if the investor demands repayment (otherwise the loan is rolled over to the next period), $Q_{i}^{t}$ the maximum amount for which this offer is valid, and $k_{i}^{t}$ is the amount of collateral posted per unit borrowed.

To simplify the presentation we assume that borrowers do not hold cash. ${ }^{16}$ Hence, if patient investors roll over their funding when middle-aged, then the

\footnotetext{
${ }^{14}$ This assumption makes sense in steady-state, because then the borrower has the same amount of both types of collateral $\left(I_{i}^{t-1}=I_{i}^{t}=I_{i}\right)$. It is a simplification because collateralization rates could in principle depend on the type of collateral. Our whole analysis holds more generally, but the exposition becomes more cumbersome.

${ }^{15}$ See, e.g., Hart and Moore (1998) or von Thadden, Berglöf and Roland (2010) for more complex models of default and renegotiation. We also abstract from reputational or other dynamic concerns, which would trade off the possible loss of future access to investor funds against current cash gains.

${ }^{16}$ It can easily be shown that holding cash is not optimal, because in the absence of shocks cash holdings are strictly dominated by real investment or immediate consumption. If there were a sufficiently large positive probability of runs in steady state, this would be different, because then cash would have value as a buffer.
} 
borrower's (per-period) profit (or free cash flow) at date $t$ is

$$
\begin{aligned}
\pi_{i}^{t}= & R_{i}\left(I_{i}^{t-2}-A_{i}^{t-1}\right)+\sum_{j} A_{i j}^{t-1} R_{j}+p_{i}^{t} A_{i}^{t}-\sum_{j} p_{j}^{t} A_{i j}^{t} \\
& +b_{i}^{t}-\alpha r_{i}^{t-1} b_{i}^{t-1}-(1-\alpha) r_{i}^{t-1} r_{i}^{t-2} b_{i}^{t-2}-I_{i}^{t} .
\end{aligned}
$$

The first term on the RHS of equation (6), $R_{i}\left(I_{i}^{t-2}-A_{i}^{t-1}\right)$, represents the return from maturing assets the borrower invested in at $t-2$, net of the assets sold at date $t-1$. The second term, $\sum_{j} A_{i j}^{t-1} R_{j}$, is the return from maturing assets the borrower purchased last period. The third and fourth terms, $p_{i}^{t} A_{i}^{t}$ and $\sum_{j} p_{j}^{t} A_{i j}^{t}$, are the proceeds of asset sales and the cost of asset purchases in the current period, respectively. The next three terms represent new borrowing, $b_{i}^{t}$, repayment to middle-aged investors, $\alpha r_{i}^{t-1} b_{i}^{t-1}$, and repayment to old-aged investors, $(1-\alpha) r_{i}^{t-2} r_{i}^{t-1} b_{i}^{t-2}$, respectively. $I_{i}^{t} \leq \overline{I_{i}}$ represents new investment.

At each date $t$, borrowers thus maximize the sum of discounted expected future cash, $\sum_{\tau=t}^{\infty} \beta^{\tau-t} \pi_{i}^{\tau}$, where $\beta<1$.

The timing of events within each period is as follows. At each date $t$,

1. investments of $t-2$ mature, young investors receive their endowments,

2. borrowers $i=1, \ldots, M$ offer contracts to investors,

3. new and patient middle-aged investors decide which of the $M$ contracts to choose, if any,

4. the $M$ asset markets open, borrowers can trade,

5 . if borrower $i$ is unable to repay all investors who demand repayment, he must declare bankruptcy. Otherwise, borrowers repay, invest $I_{i}^{t}$, and continue.

In order to have a simple coherent institutional framework, we assume that borrowers fund securities using a delivery versus payment settlement mechanism, meaning that the transfers of securities and funds happen simultaneously. The settlement is triggered by the sender of securities and cash is automatically deducted from the account of the institutions receiving the securities and credited to the account of the institution sending the 
securities. This is how Fedwire ${ }^{\circledR}$ Securities Service works, for example. This framework is consistent with standard collateralized borrowing and with repo transactions, in which the collateral actually changes ownership.

The assumption that borrowers who cannot repay at stage 5 are bankrupt simplifies the analysis without much loss of generality. Given the investors' preferences in (1), it is clear that there is no scope for rescheduling the financing from investors. Hence, if a borrower runs out of cash he must be funded by his competitors. Such arrangements may be possible, but we view them as equivalent to bankruptcy. ${ }^{17}$

\section{Steady States}

As a benchmark, this section characterizes steady-state equilibrium allocations, i.e., allocations in which contracting, trading, and investment decisions are individually optimal, feasible, and time-independent. As usual, we express all quantities per unit mass of investors.

Let $b_{i} \geq 0$ be the total amount of funds raised by borrower $i$ each period from young investors. We assume that the Law of Large Numbers also holds at the borrower level: each period the realized fraction of impatient investors at each borrower is $\alpha$. Hence, in every period, each borrower obtains funds $b_{i}$ from young investors and faces $\alpha b_{i}$ middle-aged investors and $(1-\alpha) b_{i}$ old investors for repayment. Thus there is no uncertainty about borrowers' profits, and each borrower's realized profit is equal to his expected profit.

A steady state equilibrium is a collection of $\left(b_{i}, k_{i}, I_{i}, A_{j i}, r_{i}, p_{i}\right)$ for each borrower $i$, where $k_{i}$ is collateral, $r_{i}$ the repayment promise, and $p_{i}$ the market price for assets of borrower $i$, such that no borrower and investor would prefer another funding and investment policy, given the behavior of all others, and asset markets clear. ${ }^{18}$ Aggregate feasibility requires $\sum b_{i} \leq N$.

\footnotetext{
${ }^{17}$ The distressed takeover of Bear Stearns by JP Morgan Chase in March 2008 is a case in point.

${ }^{18}$ For simplicity, we can ignore the bound $Q_{i}$ in the description of the steady state, where it can be thought of as being set to $Q_{i}=b_{i}$.
} 
For the discussion of steady states it is useful to define

$$
L_{i}=A_{i} R_{i}-\sum_{j} A_{i j} R_{j}
$$

$L_{i}$ is borrower $i$ 's net loss of future revenues from asset purchases and sales each period. Using this notation, the steady-state version of borrower $i$ 's profits (6) is

$$
\pi_{i}=\left(R_{i}-1\right) I_{i}-(1-\beta) L_{i}-\left(\alpha r_{i}+(1-\alpha) r_{i}^{2}-1\right) b_{i}
$$

The following proposition summarizes some insights from Martin, Skeie and von Thadden (2014) and extends them to the present model of shortterm borrowing with asset markets. It characterizes the steady states that will serve as the benchmark for our analysis.

Proposition 1 There are steady state equilibria in which all borrowers make strictly positive profits $\pi_{i}$. In these steady states,

- all investors roll over their loans according to their liquidity needs,

- investment is maximal: $I_{i}=\overline{I_{i}}$,

- the gross interest rate is $r_{i}=\bar{r}=1 / \beta$,

- borrowing satisfies $\sum_{i} b_{i}=N$,

$$
b_{i} \leq \frac{1+\beta}{1-\alpha+\beta} I_{i}
$$

and is otherwise indeterminate,

- collateral $k_{i}$ satisfies

$$
\frac{2}{\beta(1+\beta) R_{i}} \leq k_{i} \leq \frac{2 \beta \overline{I_{i}}}{(1-\alpha+\beta) b_{i}}
$$

and is otherwise indeterminate.

- the asset market price is $p_{i}=\beta R_{i}$, 
- asset sales and purchases are non-negative, satisfy

$$
\begin{aligned}
A_{i} & \leq \overline{I_{i}}-\frac{1}{2 \beta}(1-\alpha+\beta) b_{i} k_{i} \\
\beta^{2} L_{i} & <\frac{\beta^{2}}{1-\beta}\left(R_{i}-1\right) \overline{I_{i}}-(1-\alpha+\beta) b_{i}
\end{aligned}
$$

and are otherwise indeterminate.

The proof is given in the appendix. Along the lines of the proof in Martin, Skeie and von Thadden (2014) one can actually show the stronger statement that all steady state equilibria are either of the form described in the proposition or have zero profits with inefficient investment levels $I_{i}<\overline{I_{i}}$ for all active borrowers (there may be borrowers who are not active or who invest only internal funds). Such zero-profit equilibria may exist in some parameter configurations, but don't have to. Even if they do exist, such equilibria have little practical interest (given the large profits in practice) and have little theoretical interest for our analysis of the interplay between inside liquidity $\left(\pi_{i}>0\right)$ and outside liquidity in the case of investor runs. We therefore ignore these equilibria in the sequel and use the steady states identified in Proposition 1 as a benchmark for the rest of the analysis.

To understand why profits are positive, note that because of assumptions (3) and (4) the marginal return of investment is high if a borrower invests only a small amount of borrowed funds. At such a high rate, investment is preferred to consumption. As investment increases, the marginal return on investment eventually decreases and a borrower prefers to consume additional funds. Under our assumptions, this occurs for borrower $i$ when the kink $\overline{I_{i}}$ is reached. This is the same logic as with a smooth concave production technology. Let $f$ denote that technology, and suppose $\beta^{2} f^{\prime}(N / M)>1$, which corresponds to assumptions (3) and (4). In equilibrium, borrowers would invest their own funds until they reach a level of investment $I^{*}$, where $\beta^{2} f^{\prime}\left(I^{*}\right)=1$, so that the marginal return on consumption and investment are equal. At that level of investment, the borrower would want to equalize the return of internal and external funds and profits would be positive.

Condition (10) restricts collateralization rates in two directions. The left-hand side is the repayment constraint (5), evaluated at the equilibrium 
interest rate. Intuitively, collateral must be sufficient to incentivize the borrower to repay. The right-hand side reflects the requirement that the total amount of collateral put up in equilibrium cannot be larger than the total amount of assets available, which is $2 \overline{I_{i}}$. These two inequalities are compatible because of condition (9), which puts a cap on steady-state borrowing. Intuitively, borrowing cannot be too high, if it is to be collateralized in an incentive-compatible way.

Condition (11) states that the borrower can only sell assets that she does not use as collateral. The right-hand side of (11) is non-negative by (10). Finally, condition (12) is the equilibrium version of the condition $\pi_{i}>$ 0, using (8). Conditions (11) and (12) limit steady-state asset sales and purchases without ruling them out, because it is easy to see that the two conditions are satisfied for $A_{i}=L_{i}=0$.

The steady states of Proposition 1 all feature maximum investment and the same interest rate $\bar{r}$ and asset prices $p_{i}$, but they can differ in their borrowing $b_{i}$, collateral $k_{i}$, and securitization levels $A_{i}$. Investors are unaffected by such variations because collateral is never consumed, markets clear, and their return from lending is constant at $\bar{r}-1$. However, borrower profits are affected.

Using the equilibrium interest rate $\bar{r}$ in (8) the borrower's period profit is

$$
\pi_{i}=\left(R_{i}-1\right) \bar{I}_{i}-(1-\beta) L_{i}-\frac{1}{\beta^{2}}\left(1-\alpha+\alpha \beta-\beta^{2}\right) b_{i}
$$

Hence, for each borrower steady state profits are decreasing in borrowing $b_{i}$ and in his own securitization $A_{i}$ and are thus (partially) Pareto-ranked. In fact, the best steady states for borrower $i$ are those in which $b_{i}=A_{i}=0$, i.e., steady states in which she does not borrow and does not sell assets at all. However, zero borrowing by all borrowers is inconsistent with equilibrium. Absent borrowing, all investors would earn the storage rate of return of 0 . In an equilibrium with investment, but without borrowing, all active borrowers must make strictly positive profits because they invest their own funds and because of (3). Hence, an individual borrower can offer investors a small positive return of $\varepsilon$, consume the loan, and repay next period out of her equilibrium profits. This makes her strictly better off if $\beta(1+\varepsilon)<1{ }^{19}$

\footnotetext{
${ }^{19}$ Note that the borrower may not be able to invest the additional amount borrowed
} 
It is important to realize that borrowers have no incentive to change their borrowing or their securitization in any given steady-state equilibrium, but that they prefer other steady states. Hence, Proposition 1 is consistent with the notion that borrowers can be "trapped" in an equilibrium with high borrowing, high securitization, and low profits. Therefore, to the extent that period profits act as a buffer against adverse shocks, as we show in the following sections, borrowers with larger borrowing levels or higher levels of securitization will be more fragile.

Securitization has the advantage of bringing profits from the borrowers' asset portfolios forward, thus liberating these funds for consumption or new investment. Since the assets are sold at their fairly discounted price, the borrower earns $\beta R_{i}$ per unit sold at every date in steady-state. In contrast, the borrower would have received $R_{i}$ at $t$ if assets sold at $t-1$ had been held to maturity. So in steady state, the borrower earns $R_{i}$ per unit held to maturity at every date. This effect can be seen in equation (8), which shows that asset sales reduce steady state profits. If borrowers are not in distress, where they are forced to sell assets (as will be the case in the next sections), this reduces individual steady-state profits. In the aggregate, however, asset sales in our model simply involve a set of transfers. Aggregate profits,

$$
\pi=\sum_{i} \pi_{i}=\sum_{i}\left(R_{i}-1\right) \bar{I}_{i}-\frac{1}{\beta^{2}}\left(1-\alpha+\alpha \beta-\beta^{2}\right) N
$$

are unaffected by securitization.

\section{Single-Borrower Runs}

In the next two sections, we study under what conditions runs can occur and thus to what extent the steady state of Proposition 1 is fragile. This depends on whether only a single borrower is concerned or whether the run is systemic. We investigate the former scenario in this section and study systemic runs in Section 5.

A run cannot occur if the borrower can mobilize sufficient liquidity by reducing consumption or investment to pay all investor claims. If the bor-

because she may be capacity constrained. 
rower's steady state liquidity is insufficient, a run can occur if the investors' collateral does not provide them with sufficient protection in case of a borrower default, and if the borrower is unable to raise sufficient additional liquidity through asset sales.

As in much of the literature, we study unanticipated runs that arise from pure coordination failures, ${ }^{20}$ and assume that such coordination failures are triggered by sunspots, to which borrowers can adjust the whole contract offer as a response. The assumption is that behavior until date $t$ is as in Proposition 1, but that a sunspot occurs at the beginning of the period and indicates that borrower $i$ should not receive funding. In terms of the model, such a sunspot can be the observation of a low value of $\gamma_{i}^{t}$. As seen in Proposition $1, \gamma_{i}^{t}$ does not affect steady state activity because collateral is never liquidated. However, if the liquidation value falls below the thresholds we derive below, this may lead investors to coordinate on new expectations, which then become self-fulfilling if the investor must liquidate assets.

The question is whether this borrower can withstand the collective refusal of all their middle-aged investors to renew funding and of their young investors to provide fresh funds. Specifically, in a run all investors believe that i) no middle-aged investors renew their funding to borrower $i$, so the borrower must pay $\left[\bar{r}+(1-\alpha) \bar{r}^{2}\right] b_{i}$ to middle-aged and old investors, and ii) no new young investors lend to the borrower. We ask whether such beliefs can be self-fulfilling in a collective deviation from the steady state. Since the Law of One Price holds in steady state by Proposition 1, a trivial coordination failure may induce all investors of a given borrower to switch to another borrower out of indifference. This looks like a "run" but is completely arbitrary. We will therefore assume that investors if indifferent lend to the borrower they are financing in steady state. Hence, in order for a collective deviation from the steady state to occur we impose the stronger requirement that the individual incentives to do so must be strict.

In this section, we first derive a steady-state liquidity constraint. If in steady state the borrower has enough cash on hand to repay all claims in the event of a run, the borrower has no risk of defaulting and investors have no incentive to join in a run. If this steady-state liquidity constraint is violated,

\footnotetext{
${ }^{20}$ For a discussion see Section 6.
} 
runs are ruled out if the borrower either has enough assets to guarantee his additional borrowing through a sufficiently large haircut, or if he can raise enough additional cash in an emergency sale of his assets on the secondary market. The former possibility is addressed in subsection 4.2 by deriving a collateral constraint, the latter possibility in subsection 4.3 by deriving an emergency liquidation constraint. If any of these three constraints hold, runs cannot occur in equilibrium.

\subsection{Steady-State Liquidity}

We first consider the borrower's liquidity in steady state. In steady state, at the beginning of the period, on the asset side of his balance sheet the borrower holds $R_{i}\left(\overline{I_{i}}-A_{i}\right)$ units of cash from his own investments at date $t-2$, net of assets sold at date $t-1$, and $\sum_{j} A_{i j} R_{j}$ units of cash from his past asset purchases. He also holds securities that will yield $R_{i}\left(\overline{I_{i}}-A_{i}\right)$ units of cash at date $t+1$. Furthermore, in equilibrium the borrower raises $p_{i} A_{i}=\beta R_{i} A_{i}$ in cash by selling assets at stage 4 of the interaction of this period and buys assets at a cost of $\sum_{j} \beta_{j} R_{j} A_{i j}$. Hence, the borrower is safe and runs are not an issue if these are sufficient to pay all outstanding claims, i.e., iff

$$
\begin{aligned}
R_{i}\left(\overline{I_{i}}-A_{i}\right)+ & \sum_{j} A_{i j} R_{j}+\beta R_{i} A_{i} \geq\left[\bar{r}+(1-\alpha) \bar{r}^{2}\right] b_{i}+\sum_{j} \beta R_{j} A_{i j} \\
& \Leftrightarrow R_{i} \overline{I_{i}}-(1-\beta) L_{i} \geq\left[\bar{r}+(1-\alpha) \bar{r}^{2}\right] b_{i}
\end{aligned}
$$

where we have used (7). In this case, the borrower does not need to change his asset market behavior to satisfy all the additional liquidity demand. Under this strategy, the borrower first reduces her consumption, and then, if this reduction does not mobilize enough cash, her investment. Anticipating this, investors have no incentive to deviate from the steady-state and a run cannot occur.

Re-writing (15) using $\bar{r}=1 / \beta$ yields the borrower's "steady-state liquidity constraint"

$$
\beta^{2}(1-\beta) L_{i} \leq \beta^{2} R_{i} \overline{I_{i}}-(1-\alpha+\beta) b_{i}
$$

Condition (16) is violated if $L_{i}$ is too large, i.e., if the borrower relies too much on asset sales to finance current consumption in steady-state. In 
this case, he does not have enough liquidity in equilibrium to stave off a run. Conversely, if (16) holds, the borrower's steady state liquidity is sufficient to repay all outstanding claims in a run. By our assumption that the incentives to run must be strict, this yields the following result.

Proposition 2 If borrower $i$ satisfies the steady-state liquidity constraint (16), there are no strict incentives to run on this borrower. Conversely, if (16) is violated, the borrower does not have sufficient steady-state liquidity to withstand a run.

Condition (16) is strictly stronger than condition (12) of Proposition 1. Hence, there are steady states in which the borrower's balance sheet is so weak - either through high $L_{i}$ on the asset side or high $b_{i}$ on the liability side - that he does not have enough steady-state liquidity to withstand a run.

\subsection{Collateral}

We now assume that (16) is violated and ask whether the borrower can put up enough additional collateral to attract the missing liquidity in case of a run.

The amount of missing cash the borrower needs to attract is

$$
\begin{aligned}
m_{i} & \equiv\left(\bar{r}+(1-\alpha) \bar{r}^{2}\right) b_{i}-R_{i}\left(\overline{I_{i}}-A_{i}\right)-\sum_{j} A_{i j} R_{j} \\
& =\left(\bar{r}+(1-\alpha) \bar{r}^{2}\right) b_{i}-R_{i} \overline{I_{i}}+L_{i}
\end{aligned}
$$

The total amount of collateral available in a run is the total amount of invested assets, $\overline{I_{i}}$, that will mature in $t+1$. These assets can be used to attract the cash shortfall $m_{i}$. To increase collateralization rates to stave off the run, the borrower can reduce her borrowing level by adjusting the borrowing limit $\widehat{Q}_{i}$, which effectively allows her to increase the collateral per unit borrowed. Hence, the maximum possible value of collateral per unit borrowed is

$$
\bar{k}_{i}=\overline{I_{i}} / m_{i}
$$

There are two different investor groups the borrower can borrow from, young investors who hold cash and middle-aged investors who hold a loan to the borrower that may be rolled over. 


\begin{tabular}{l|l|l|}
\multicolumn{3}{c}{ other investors } \\
& invest & don't \\
\hline invest & $\widehat{r}_{i}$ & $\gamma_{i}^{t} R_{i} \widehat{k}_{i}$ \\
\hline don't & $\bar{r}$ & $\bar{r}$ \\
\hline
\end{tabular}

Table 1: Payoffs to young investors in an isolated run

Table 1 gives the payoff to an individual young investor at date $t+1$ as a function of the collective behavior of all other investors. Since the run is on this borrower only, the other borrowers operate as in steady state, and investors can switch to them to invest their cash if they wish to. If the other investors lend to the borrower (invest), only interest rates matter, and the investor is paid a gross return $\widehat{r}_{i}$ if he finances $i$, and $\bar{r}$ if he switches. If the other investors do not finance $i$, the fact that (16) is violated implies that the borrower will go bankrupt and thus only collateral matters. Hence, the run outcome (don't, don't) is not a strict equilibrium if and only if

$$
\gamma_{i}^{t} R_{i} \widehat{k}_{i} \geq \bar{r}
$$

This inequality can be made to hold if and only if it holds for $\widehat{k}_{i}=\bar{k}_{i}$. Note that the borrower can attract as many young investors as necessary to fund the shortfall $m_{i}$ if he has the collateral, because he can compete away lenders from other borrowers if his offer is sufficiently attractive. Inserting $m_{i}$ from (17) in (19) yields the following collateral constraint.

Proposition 3 If borrower $i$ satisfies the collateral constraint

$$
\beta^{2} L_{i} \leq\left(1+\gamma_{i}^{t} \beta\right) \beta^{2} R_{i} \overline{I_{i}}-(1-\alpha+\beta) b_{i}
$$

there are no strict incentives to run on this borrower. Conversely, if (21) is violated, the borrower does not have sufficient collateral to withstand a run.

Proof. Condition (21) is (20) evaluated at $\bar{k}_{i}=\bar{I}_{i} / m_{i}$. We already have shown that this condition is sufficient to prevent a run, because young lenders 
will fund the shortfall if it holds. In order to prove necessity, we must examine the incentives of middle-aged patient investors to roll over their existing loans.

Suppose therefore that condition (21) is violated. From (17), only a fraction

$$
\varphi \equiv \frac{R_{i} \bar{I}_{i}-L_{i}}{b_{i}\left[\bar{r}+(1-\alpha) \bar{r}^{2}\right]} \in(0,1)
$$

of middle-aged investors can get their money back before the borrower becomes illiquid. With probability $1-\varphi$, patient middle-aged lenders who run are forced to keep their collateral. Lenders who are able to obtain their cash back can invest it with another borrower. The payoffs of patient middle-aged lenders (per unit of funds) are therefore as in the following table.

\begin{tabular}{l|l|l|}
\multicolumn{3}{c}{ other investors } \\
& invest & don't \\
\hline invest & $\widehat{r}_{i}$ & $\gamma_{i}^{t} R_{i} \widehat{k}_{i}$ \\
\hline don't & $\bar{r}$ & $\varphi \bar{r}+(1-\varphi) \gamma_{i}^{t} R_{i} k_{i}$ \\
\hline
\end{tabular}

Table 2: Payoffs to middle-aged patient investors in an isolated run

Table 2 differs from Table 1 in the lower right cell, which reflects the different positions of young and patient middle-aged investors. The outcome (don't, don't) is strictly optimal for the individual patient middle-aged investor if and only if

$$
\gamma_{i}^{t} R_{i} \widehat{k}_{i}<\varphi \bar{r}+(1-\varphi) \gamma_{i}^{t} R_{i} k_{i}
$$

This condition holds for all $k_{i}$ and $\widehat{k}_{i}$ iff it holds for $\widehat{k}_{i}=\bar{k}_{i}$ from (19) and $k_{i}=2 / \beta(1+\beta) R_{i}$ from (10). Re-writing (23) for these two extreme values 
and setting $d_{i} \equiv \bar{I}_{i} / b_{i}$ yields

$$
\begin{aligned}
& \gamma_{i}^{t} R_{i} \frac{d_{i}}{\bar{r}+(1-\alpha) \bar{r}^{2}-R_{i} d_{i}+L_{i} / b_{i}} \\
< & \varphi \bar{r}+(1-\varphi) \gamma_{i}^{t} R_{i} \frac{2}{\beta(1+\beta) R_{i}} \\
\Leftrightarrow & \frac{\gamma_{i}^{t} \beta^{4} d_{i} R_{i}}{1-\alpha+\beta-\beta^{2} d_{i} R_{i}+L_{i} \beta^{2} / b_{i}} \\
< & \frac{\beta^{3} d_{i} R_{i}-L_{i} \beta^{3} / b_{i}}{1-\alpha+\beta}+\left(\frac{2 \gamma_{i}^{t}}{\beta(1+\beta)}\right)\left(\frac{1-\alpha+\beta-\beta^{2} d_{i} R_{i}+\beta^{2} L_{i} / b_{i}}{1-\alpha+\beta}(27)\right. \\
\Leftrightarrow \quad & (1-\alpha+\beta) \gamma_{i}^{t} \beta^{4} d_{i} R_{i}<\left[\beta^{3} d_{i} R_{i}-L_{i} \beta^{3} / b+\frac{2 \gamma_{i}^{t}}{\beta(1+\beta)} \Psi\right] \Psi
\end{aligned}
$$

where $\Psi \equiv\left(1-\alpha+\beta-\beta^{2} d_{i} R_{i}+\beta^{2} L_{i} / b_{i}\right)$.

Since (21) is violated, we have

$$
1-\alpha+\beta-\beta^{2} d_{i} R_{i}+L_{i} \beta^{2} / b>\gamma_{i}^{t} \beta^{3} d_{i} R_{i}
$$

Suppose first that $\gamma_{i}^{t}>\beta$. By (29), it is enough to show that

$$
\beta(1-\alpha+\beta) \leq \beta^{3} d_{i}\left(R_{i}-\frac{L_{i}}{\bar{I}_{i}}\right)+\gamma_{i}^{t}\left(1-\alpha+\beta-\beta^{2} d_{i}\left(R_{i}-\frac{L_{i}}{\bar{I}_{i}}\right)\right.
$$

which is implied by (29), (11), and (10).

Now suppose that $\gamma_{i}^{t} \leq \beta$. (28) is linear in $\gamma_{i}^{t}$ and holds for $\gamma_{i}^{t}=0$ and for $\gamma_{i}^{t}=\beta$. Hence, it holds for all $\gamma_{i}^{t} \leq \beta$.

If the borrower has collateral to attract enough young investors, then he is safe from runs. In particular, he can replace any middle-aged investor that does not want to roll over her loan with a new young investor. Conversely, if the borrower cannot attract enough young investors, then he cannot withstand a run, because middle-aged investors run if young investors choose to do so.

Condition (21) is implied by the steady-state borrowing restriction (9) if $\gamma_{i}^{t}$ is close to 1 and $L_{i}$ is small enough, and is stronger if $\gamma_{i}^{t}$ is small and if $L_{i}$ is large. Hence, when the borrower is holding an "adequate" amount of assets in "normal" times, the collateral constraint is not violated, and it 
becomes relevant only in "stress" time (when $\gamma_{i}^{t}$ is small). Furthermore, the collateral constraint of borrower $i$ is more likely to be violated if short-term borrowing $b_{i}$ is large, and if profitability $R_{i}$ and investment capacity $\bar{I}_{i}$ are small.

Comparing the steady state liquidity constraint (16) and the collateral constraint (21) shows under what conditions the posting of additional collateral can provide sufficient additional liquidity.

Lemma 1 The collateral constraint (21) is weaker than the steady-state liquidity constraint (16) iff

$$
L_{i}<\gamma_{i}^{t} R_{i} \bar{I}_{i}
$$

Hence, if (30) holds, it is possible that a borrower may have enough collateral to prevent a run even if it does not have sufficient steady-state liquidity. This lemma illustrates some interesting insights of the model. First, by Proposition 1, collateral value does not matter in steady-state, because investors never liquidate their collateral and therefore do not have to value it. However, the lemma shows that collateral can play a role to prevent a run. If the quality of the collateral is high enough, it provides a good liquidity hedge. In other words, with collateral of high quality $\left(\gamma_{i}^{t}\right.$ large), investors have no concern about the default risk of borrowers. By (30), "high" here is defined relative to the borrower's asset market exposure $L_{i} / \bar{I}_{i}$.

The events of 2007 - 2009 suggest that the quality of securities can change quickly. Before the financial crisis, a wide variety of securities, including private label MBS and ABS, could be financed as if they were very liquid. However, in 2007, haircuts for these securities increased dramatically in some markets, reflecting increased market liquidity concerns (see, e.g., Gorton and Metrick 2012). Ultimately, this led to a reversal of inequality (30), which made it impossible for many players to obtain liquidity against additional collateral, in particular for those who where heavily engaged in the shadow banking system through asset sales and similar activities (high $L_{i}$ ).

For these borrowers only fire sales of their assets remained as an option to obtain additional liquidity, to the analysis of which we turn now. 


\subsection{Asset Liquidation}

If a borrower does not have sufficient steady-state liquidity or enough collateral to prevent a run, he must turn to emergency liquidation sales of assets. Selling an amount $\widehat{A}_{i}, A_{i}<\widehat{A}_{i} \leq \overline{I_{i}}$, of assets yields $p_{i} \widehat{A}_{i}$ in current liquidity and reduces his cash at date $t+1$ by $R_{i} \widehat{A}_{i}$. Note that $p_{i}$ is an out-ofequilibrium asset price, which affects all his asset sales. The borrower's cash position during a run at date $t$ therefore is

$$
\begin{aligned}
I_{0} & =R_{i}\left(\overline{I_{i}}-A_{i}\right)+\sum_{j} A_{i j} R_{j}+p_{i} \widehat{A}_{i}-\left(\bar{r}+(1-\alpha) \bar{r}^{2}\right) b_{i} \\
& =R_{i} \bar{I}_{i}-L_{i}+p_{i} \widehat{A}_{i}-\left(\bar{r}+(1-\alpha) \bar{r}^{2}\right) b_{i} .
\end{aligned}
$$

The cash position corresponds to the return on assets held by the borrower and maturing today, $R_{i}\left(\overline{I_{i}}-A_{i}\right)+\sum_{j} A_{i j} R_{j}$, plus the proceeds from assets sale, $p_{i} \widehat{A}_{i}$, minus the amounts that must be repaid to running investors $(\bar{r}+$ $\left.(1-\alpha) \bar{r}^{2}\right) b_{i}$. Note that the borrower can adjust his asset sales and purchases in response to the run. Clearly, it is not optimal for a borrower subject to a run to purchase assets.

If $I_{0}<0$ the borrower does not have the liquidity to stave off the run and is bankrupt. If $I_{0} \geq 0$, the borrower can adjust his future funding and investment and survive the run. Indeed, since after a run the borrower will have $R_{i}\left(\overline{I_{i}}-\widehat{A}_{i}\right)$ in cash and nothing to repay in $t+1$, he can continue operations by investing at date $t+1$ and save and invest thereafter.

As derived in (17), the amount of cash the borrower must raise in the asset market is $m_{i}$. If in asset market equilibrium $p_{i} \widehat{A}_{i} \geq m_{i}$, the borrower survives the run, if not he will be bankrupt. Whether he can raise enough cash through the asset sale depends on the cash in the market (Allen and Gale, 1994), i.e., on the total amount of cash held by all other borrowers, and on their willingness to buy his assets.

Cash in the market is the cash available to all other borrowers after a run on borrower $i$ before asset market activity and investment. It consists of the total returns from 2-period old investments net of the steady-state loan repayments, plus all new loans including the funds $b_{i}+(1-\alpha) \bar{r} b_{i}$ that are 
not going to borrower $i$ in the run. The cash available to borrower $j \neq i$ is

$$
c_{j}=R_{j}\left(\overline{I_{j}}-A_{j}\right)+\sum_{k} R_{k} A_{j k}-\left(\alpha \bar{r}+(1-\alpha) \bar{r}^{2}-1\right) b_{j}
$$

Hence, total cash in the market is

$$
\begin{aligned}
C_{i}= & \sum_{j \neq i} c_{j}+b_{i}+(1-\alpha) \bar{r} b_{i} \\
= & \sum_{\substack{j \neq i\\
}} R_{j}\left(\overline{I_{j}}-A_{j}\right)+\sum_{\substack{j \neq i\\
}} \sum_{k} R_{k} A_{j k} \\
& -\left(\alpha \bar{r}+(1-\alpha) \bar{r}^{2}-1\right) N+\left(\bar{r}+(1-\alpha) \bar{r}^{2}\right) b_{i}
\end{aligned}
$$

Lemma 2 For all $i$,

$$
C_{i}>m_{i}
$$

Proof. By definition,

$$
A_{i}=\sum_{j} A_{j i}
$$

Hence,

$$
\sum_{i} A_{i}=\sum_{i, j} A_{j i}
$$

which implies that

$$
\begin{aligned}
\sum_{i}\left(A_{i} R_{i}-\sum_{j} A_{i j} R_{j}\right) & =\sum_{i} \sum_{j} A_{j i} R_{i}-\sum_{i} \sum_{j} A_{i j} R_{j} \\
& =0
\end{aligned}
$$

Hence, (34) and (17) imply that

$$
C_{i}-m_{i}=\sum_{j} R_{j} \overline{I_{j}}-\frac{1}{\beta^{2}}\left(1-\alpha+\alpha \beta-\beta^{2}\right) N
$$

which is strictly positive by (14). 
(37) - (38) in the above proof show that, as noted in Section 3, individual net equilibrium exposures to asset market activity wash out in the aggregate:

$$
\sum_{i} L_{i}=0
$$

Intuitively, a run on borrower $i$ simply means a redistribution of his liquidity to the other borrowers. Hence, (39) implies that the cash in the market after a run is sufficient to cover the shortfall of any individual borrower (Lemma 2). Since in steady state aggregate liquidity is sufficient to repay all investors and to invest maximally by (14), the same is true for the set of all borrowers without $i$, because the remaining borrowers have sufficient investment capacity by (4).

The question is whether this cash can be mobilized to save the borrower.

Proposition 4 If the steady state liquidity constraint (16) is violated, then asset sales give borrower $i$ sufficient liquidity in a run if and only if his "emergency liquidation constraint" holds:

$$
\beta^{2} L_{i} \leq(1+\beta) \beta^{2} R_{i} \bar{I}_{i}-(1-\alpha+\beta) b_{i}
$$

Proof. Consider the market for borrower $i$ 's assets when he is run upon. The benefits to other borrowers from buying these assets are the asset returns in $t+1$, the cost is the foregone consumption in $t$. Therefore, aggregate demand for these assets will be 0 if $p_{i}>\beta R_{i}$ and maximal if $p_{i}>\beta R_{i}$. Formally,

$$
D_{i}\left(p_{i}\right)= \begin{cases}0 & \text { if } p_{i}>\beta R_{i} \\ \frac{C_{i}}{p_{i}} & \text { if } p_{i}<\beta R_{i}\end{cases}
$$

In terms of supply, borrower $i$ must raise $m_{i}$. The borrower will be able to raise enough cash from the asset sale to cover $m_{i}$ if and only if

$$
p_{i} \geq \frac{m_{i}}{\overline{I_{i}}} \equiv \underline{p_{i}}
$$

Suppose $\underline{p_{i}}>\beta R_{i}$. Then either $p_{i} \geq \underline{p_{i}}$, in which case other borrowers do not purchase $i$ 's assets, or $p_{i}<\underline{p_{i}}$, in which case the price is too low to save $i$. 
Now suppose that $p_{i} \leq \beta R_{i}$. Consider any $p_{i}$ such that $p_{i} \leq p_{i}<\beta R_{i}$, if it exists. Then the borrower supplies $\frac{m_{i}}{p_{i}}$ units of his asset, and (41) and Lemma 2 imply that aggregate excess demand on the market is strictly positive. However, if $p_{i}=\beta R_{i}$ demand is indeterminate in the range $\left[0, \frac{C_{i}}{\beta R_{i}}\right]$ and supply is indeterminate in the range $\left[\frac{m_{i}}{p_{i}}, \bar{I}_{i}\right]$. By Lemma 2, the market clears, and the borrower obtains sufficient cash to stave off the run.

Re-writing the condition $p_{i} \leq \beta R_{i}$ and using (7) in (17) yields

$$
\left(\bar{r}+(1-\alpha) \bar{r}^{2}\right) b_{i}-R_{i} \overline{I_{i}}+L_{i} \leq \beta R_{i} \overline{I_{i}}
$$

Substituting in for $\bar{r}$ and simplifying yields (40).

Condition (40) is the borrower's "emergency liquidation constraint": it indicates when a borrower can mobilize sufficient liquidity to survive an isolated run, if he liquidates his assets on the secondary market. This constraint is to be distinguished from the borrower's "steady state liquidity constraint" (16), which indicates when the borrower has sufficient liquidity in steady state if he simply follows his steady state asset market policy.

Note that the right-hand side of (40) is positive by (9). Hence, condition (40) is satisfied if the borrower's net exposure to the asset market in steady state is non-positive, i.e., if $L_{i} \leq 0$ (no securitization). However, condition (40) can be violated in equilibrium, because by (3) the right-hand side of (12) in Proposition 1 is strictly greater than the right-hand side of (40). Hence, there are steady-state values of $L_{i}$ that violate (40).

\subsection{A Pecking Order}

In fact, the three conditions that determine whether the borrower can stave off a run are nested in a remarkably simple and intuitive way.

Lemma 3 The steady state liquidity constraint (16) and the collateral constraint (21) are both stricter than the emergency liquidation constraint (40). All three constraints are stricter than the steady state feasibility constraint (12). 
Proof. (16) implies (40) if $\beta R_{i} \bar{I}_{i} \geq \beta L_{i}$, which is true because $L_{i} \leq A_{i} R_{i}$ and $A_{i} \leq \overline{I_{i}}$. (21) implies (40) if $\left(1+\gamma_{i}^{t} \beta\right) \beta^{2} R_{i} \bar{I}_{i} \leq(1+\beta) \beta^{2} R_{i} \overline{I_{i}}$ which holds because $\gamma_{i}^{t}<1$. The last statement follows by transitivity because we have already shown that (40) implies (12).

Lemma 3 implies a kind of "pecking order" to stave off runs in steady state:

- If $L_{i}$ and $b_{i}$ are sufficiently low, the borrower can mobilize sufficient liquidity by reducing consumptions (i.e. cutting dividends) and cutting down on investment.

- For larger $L_{i}$ and $b_{i}$ the borrower is able to obtain sufficient additional liquidity through additional collateral if his collateral quality is high (condition (30)).

- For even larger $L_{i}$ and $b_{i}$ neither of the above is possible, but the borrower can raise sufficient additional liquidity through asset sales.

- There are steady states in which $L_{i}$ and $b_{i}$ are so high that the borrower is unable to stave off a run.

Note that when both asset sales and collateral can be used to obtain outside liquidity the borrower is indifferent between the two, since asset sales occur at a fair price.

The ordering of the constraints in Lemma 3 makes it possible to summarize the possibility of a run in the following simple proposition.

Proposition 5 A run on a single borrower $i$ is impossible iff his emergency liquidation constraint (40) holds. Otherwise, neither asset sales nor additional collateral provide enough liquidity and the run bankrupts the borrower if it occurs.

The comparative statics of the pivotal constraint (40) are simple and intuitive. A run is possible if 
- Asset market exposure $L_{i}$ is large

- Short-term borrowing $b_{i}$ is large

- Borrower size $\bar{I}_{i}$ is small

- Borrower profitability $R_{i}$ is low.

In general, condition (40) involves the asset side $\left(L_{i}\right)$ and the liability side $\left(b_{i}\right)$ of the borrower's balance sheet. However, two simple special cases are worth noting in which the solidity of one side of the balance sheet is sufficient for stability.

Corollary 1 A run on a single borrower $i$ is impossible if

- $L_{i} \leq 0$, or

- $(1-\alpha+\beta) b_{i} \leq \beta^{3} R_{i} \bar{I}_{i}$.

Proof. The case of $L_{i}$ is covered by Lemma 4 because the right-hand side of (40) is positive. For the second case note that under this condition the steady-state liquidity constraint (16) holds for all $L_{i} \leq R_{i} \bar{I}_{i}$ (remember that this is the maximum value $L_{i}$ can take).

As noted above, a larger $L_{i}$ weakens the borrower's asset side and reduces the amount of liquidity available to the borrower in case of emergency. When $L_{i} \leq 0$ the borrower's balance sheet is boosted by his strong net asset position and there is enough cash in the market to purchase all his assets at a fair price, by lemma 2. Borrowers can also withstand an isolated run if their leverage is sufficiently small, since in that case there are relatively few running investors to pay. The second condition of corollary 1 provides a bound on the borrower's leverage, below which he has sufficient steady-state liquidity to withstand a run. 


\section{Systemic Runs}

A systemic run is a collective decision by all investors not to lend to any of the $M$ borrowers but rather to hoard their money and store it. In this section we ask whether and under what conditions such a systemic run can occur and is individually rational for investors. As in the previous section, we study unanticipated runs that arise from pure coordination failures. Behavior until date $t$ is as in Proposition 1 and the question is whether the borrowers can withstand the collective refusal of all their investors to provide funding.

The two main differences to the analysis of the previous section are that (i) there is no market for assets if all borrowers are distressed, and (ii) investors who do not continue to lend as in steady state cannot lend to other borrowers. As we will see, this implies that each borrower's collateral constraint (21) becomes easier to satisfy and the steady-state liquidity constraint (16) becomes tighter. The emergency liquidity constraint (40) loses its meaning in this context, because borrowers cannot access the asset market as in steady state. Hence, there is only one "liquidity constraint".

\subsection{Collateral}

If the cash shortfall $m_{i}$ without asset market activity defined by (17) is positive, the borrower can again reduce her borrowing level by changing $\widehat{Q}_{i}$, as in Section 4.2, and thus increase the collateral per unit borrowed. When young investors consider such a debt offer by a borrower, they now compare it to the alternative of hoarding their cash, because they cannot lend to other borrowers. Hence, the game played between young investors is given by the following modification of Table 1 .

\begin{tabular}{l|l|l|}
\multicolumn{3}{c}{ other investors } \\
& lend & don't \\
\hline lend & $\widehat{r}_{i}$ & $\gamma_{i}^{t} R_{i} \widehat{k}_{i}$ \\
\hline don't & 1 & 1 \\
\hline
\end{tabular}

Table 3: Payoffs to young investors in a systemic run 
Table 3 gives the payoff to an individual young investor at date $t+1$ as a function of the collective behavior of all other investors. The difference to Table 1 is the payoff to not lending, which is now 1 instead of $\bar{r}$. Here, the run outcome (don't, don't) is not a strict equilibrium if and only if

$$
\gamma_{i}^{t} R_{i} \widehat{k}_{i} \geq 1
$$

This inequality can be made to hold if and only if it holds for $\widehat{k}_{i}=\bar{k}_{i}=$ $\overline{I_{i}} / m_{i}$ as defined in (19). Again the borrower can attract as many young lenders as necessary to fund the shortfall $m_{i}$ if he has the collateral, because the alternative to investors is simple storage. With a proof along the lines of the previous section, we thus obtain the following collateral constraint.

Proposition 6 If borrower $i$ satisfies the systemic collateral constraint

$$
\beta^{2} L_{i} \leq\left(1+\gamma_{i}^{t}\right) \beta^{2} R_{i} \overline{I_{i}}-(1-\alpha+\beta) b_{i}
$$

there are no strict incentives for a systemic run. Conversely, if (43) is violated for all $i$, then there is not enough collateral in the system to withstand a systemic run.

The only difference between condition (43) in the systemic case and condition (40) in the isolated-run case is that the latter has the expression $(1+\beta)$ in the first term on the right side, while the former replaces this expression with the expression $\left(1+\gamma_{i}^{t}\right)$. The latter case has the asset being transferred at a fair market price, which is the discounted value of return $R_{i}$, while the former case has the asset being used as collateral by a group of second-best users, reflected by $\gamma_{i}^{t} R_{i}$. The systemic collateral constraint (43) is weaker than the collateral constraint (21) for isolated runs, because in a systemic run the alternative to lending to a particular borrower is less attractive. As far as collateral is concerned, borrowers therefore find it easier to borrow in a systemic run than if the run targets them in isolation.

Furthermore, as in the case of isolated runs, condition (43) is implied by the steady-state borrowing restriction (9) if $\gamma_{i}^{t}$ is close to 1 and $L_{i}$ is small, and is stronger if $\gamma_{i}^{t}$ is small and if $L_{i}$ is large. Hence, when the borrower is holding a sufficient amount of assets in "normal" times, the collateral constraint is not violated, and it becomes relevant only in "stress" time (when $\gamma_{i}^{t}$ is small). 


\subsection{Liquidity}

In a market-wide run, borrowers cannot obtain liquidity on the market, because nobody is ready to buy assets, and the market fails. This is the extreme case of insufficient cash-in-the-market in Allen and Gale (1994). Borrowers therefore have the liquidity to withstand the run if and only if they have sufficient cash on their own, i.e., iff $I_{0} \geq 0$ for $\widehat{A}_{i}=0$ as defined in (31). In this case, the borrower can only rely on the return from maturing securities and neither asset sales nor purchases can occur. Writing this condition out explicitly yields the following result.

Proposition 7 A borrower $i$ has sufficient liquidity to withstand a systemic run if and only if

$$
\beta^{2} L_{i} \leq \beta^{2} R_{i} \overline{I_{i}}-(1-\alpha+\beta) b_{i}
$$

Condition (44) is the borrower's systemic liquidity constraint. It is stricter than the emergency liquidation constraint (40) of individual borrower runs by direct inspection; and indeed, clearly liquidity is scarcer in a systemic run.

\section{$5.3 \quad$ Fragility}

It is easy to see that condition (44) is stricter than the systemic collateral constraint (43). Hence, for systemic runs, the liquidity constraint is violated first, and, unlike in the case of individual runs, the collateral constraint is the crucial constraint. ${ }^{21}$

Propositions 6 and 7 therefore imply the following characterization of systemic fragility.

Proposition 8 A systemic run is possible if and only if the collateral constraint (43) is violated for all borrowers, i.e., iff

$$
\beta^{2} L_{i}>\left(1+\gamma_{i}^{t}\right) \beta^{2} R_{i} \overline{I_{i}}-(1-\alpha+\beta) b_{i}
$$

for all $i$.

\footnotetext{
${ }^{21}$ Remember that a systemic run cannot occur if one of the two constraints is satisfied for one borrower.
} 
Condition (45) can be read as a condition on the outside collateral value $\gamma_{i}^{t}$. Simple rearranging yields

$$
\gamma_{i}^{t}<\frac{1}{\beta^{2} R_{i} \bar{I}_{i}}\left[\beta^{2} L_{i}+(1-\alpha+\beta) b_{i}\right]-1
$$

If (44) is violated, the right-hand side of (46) is strictly positive. Hence, if all the $\gamma_{i}^{t}$ drop sufficiently low, then (45) holds for each $i$, and a systemic run can occur. If, as suggested earlier, drops in $\gamma_{i}^{t}$ produce the sunspots that make investors lose their faith in the borrowers, then systemic runs are a possible self-fulfilling prophecy if shocks to the valuation of collateral are sufficiently strong and uniform across assets.

As discussed in Section 3, equilibrium in our economy requires that total borrowing is constant at the exogenous level of loanable funds $N$. Proposition 8 therefore implies the following sufficient condition for systemic stability.

Proposition 9 A systemic run at time $t$ is impossible if

$$
\sum_{i} \gamma_{i}^{t} \bar{I}_{i} \geq(\beta-\alpha) N
$$

Proof. In a systemic run, all inequalities (45) hold. Adding up and using (39) yields

$$
\begin{aligned}
& \sum_{i}(1-\alpha+\beta) b_{i}>\sum_{i}\left(1+\gamma_{i}^{t}\right) \beta^{2} R_{i} \overline{I_{i}} \\
\Leftrightarrow \quad & (1-\alpha+\beta) N>\sum_{i}\left(1+\gamma_{i}^{t}\right) \beta^{2} R_{i} \overline{I_{i}}
\end{aligned}
$$

by point 4 in Proposition 1. Because of (3) and (4), this is impossible if (47) holds.

Proposition 9 only gives a sufficient condition, but is still of some interest because it draws attention to the variables that matter for systemic stability. The proposition implies in particular that systemic runs are impossible if $\alpha \geq \beta$. $\alpha$ is the aggregate degree of impatience in the economy; hence, $1-\alpha$ measures how much funding will be rolled over in equilibrium. If that amount is very small, the system operates on a short-term basis and is not particularly 
vulnerable with respect to runs. However, if a sufficient amount of funding is obtained by rolling over short-term funding, i.e., if there is sufficient maturity transformation, is the system in danger of becoming unstable.

If this is the case, ceteris paribus, condition (47) shows that systemic runs are less likely for smaller funding markets (small $N$ ) and for financial technologies for which liquidation losses cannot be too large $\left(\gamma_{i}^{t}\right.$ sufficiently bounded away from 0 ).

\section{Liquidity Provision and Regulation}

In our model, runs are unexpected because sunspots do not occur in equilibrium. The model may therefore not appear suitable for policy advice. There are at least three reasons why this conclusion is premature.

First, in addition to simplifying the analysis, there are serious behavioral reasons to believe that market participants underestimate the probability of breakdowns. This is a standard argument in economic psychology (e.g. Kahneman 2011), and has been argued in the case of the recent financial crisis, among others, in the "neglected risks" model by Gennaioli, Shleifer, and Vishny (2012). The very high degrees of leverage observed before the panic and the lack of liquidity observed ex post for some institutions would be consistent with this interpretation.

Second, our model should be thought of as the limiting case of a more general model where sunspots occur with some probability $q>0$. Since the more general model would be continuous in $q$, our results carry over to equilibrium sunspots that occur with sufficiently small probability. This is the approach in models such as Kiyotaki and Moore (1997), Brunnermeier and Pedersen (2009) or Uhlig (2010). ${ }^{22}$

Third, and perhaps most importantly, our results carry over to the model with $q>0$ even before the limit, in the form of sufficient conditions for stability. If the liquidity or collateral conditions that we have identified in Sections 4 and 5 hold, then there are no strict incentives to run in reaction to sunspots, whenever they occur, on or off the equilibrium path. As this is

\footnotetext{
${ }^{22}$ See Allen and Gale (2004a) for a careful analysis of the limiting process for $q \rightarrow 0$, and Postlewaite and Vives (1986) for an analysis of equilibrium runs.
} 
so, steady state behavior will be as described in Proposition 1. Of course, if these conditions do not hold, rational market participants can adjust their behavior to the probability of sunspots, and steady states will be different. Hence, our analysis provides insights into sufficient conditions for stability in a more general model, even if these may not be necessary.

Given these considerations, we now turn to policy considerations. Our model has different policy implications for individual and systemic runs. If individual runs are a policy concern, the model suggests that prudential regulation, as suggested by Basel III, improves financial stability. In contrast, addressing the risk of systemic runs requires some lender-of-last-resort tools.

In terms of efficiency, runs on individual borrowers only result in a reallocation of liquidity, if the emergency liquidation constraint (40) holds, and not in losses. Hence, regulation may not be required, as it would be enough to rely on the borrowers' self interest to operate with borrowing levels and asset sales consistent with (40). If there are other reasons to be concerned with individual runs (not modeled in this paper), then the conditions under which borrowers are immune to individual runs, summarized in Proposition 5, suggest the following policy implications. First, borrowers are immune to runs if $L_{i}$ is sufficiently small. Hence, constraints that require borrowers to maintain a sufficient stock of assets that they can sell in an emergency will increase financial stability. The liquidity coverage ratio (LCR), the ratio of unencumbered, high quality liquid assets to total net cash outflows a bank would experience within a 30-day time horizon, proposed by Basel III, would play such a role. Second, runs are related to leverage in our model, so leverage constraints, a standard prudential tool, will also enhance financial stability in our model.

In a systemic run, all borrowers must sell assets to survive, and hence the asset market breaks down. But this is inefficient, as the asset returns are unaffected and, if the price reflected the assets' fundamental value, borrowers would be able to survive. This suggests a role for a lender of last resort. Access to a lender of last resort is a standard tool used to strengthen the banking sector in the face of financial fragility. Theoretical work has shown how access to a lender of last resort can prevent bank runs. ${ }^{23}$ In the

\footnotetext{
${ }^{23}$ Diamond and Dybvig (1983) originally showed how deposit insurance can prevent runs
} 
U.S., the broker-dealers that rely on the tri-party repo market as a source of short-term funding did not have direct access to the discount window. This lack of access to emergency liquidity proved destabilizing during the crisis and motivated the Federal Reserve to introduce the Primary Borrower Credit Facility (PDCF). Similar concerns about MMMFs, who represent an important share of investors in the tri-party repo market, motivated the creation of the Asset-Backed Commercial Paper Money Market Mutual Fund Liquidity Facility (AMLF), and the Money Market Investor Funding Facility (MMIFF). These facilities were temporarily created under section 13.3 of the Federal Reserve Act, which allows the Federal Reserve to lend to a variety of institutions under unusual and exigent circumstances.

In the context of our model, a "buyer of last resort" could inject the necessary liquidity in the secondary market by simply purchasing the assets. Similarly, a lender of last resort can lend cash to borrowers taking the assets as collateral. This institution would need to be ready to inject $\sum_{i} m_{i}$, which is just enough to maintain the price if all borrowers suffer from a run. Note that the commitment to inject the liquidity is sufficient to prevent systemic runs and thus to keep all investors on the steady state. In equilibrium the liquidity injection will not be executed, as is the case in Diamond and Dybvig (1983).

Interestingly, comparing Proposition 5 and Proposition 8 shows that in stress times, when $\gamma_{i}^{t}<\beta$, the systemic fragility constraints are stricter than the individual fragility constraints for all $i$. Hence, if regulation wants to prevent systemic runs, it must impose the stricter restrictions (43) on all borrowers. This automatically rules out runs on individual borrowers.

In order to rule out systemic runs for sure, the systemic collateral constraints (43) must be based on the worst-case scenario of the lower bound of the support of the shocks $\gamma_{i}^{t}$. Assessing the support of these distributions is clearly a difficult task for regulators. If the supports are not clearly bounded

by taxing to pay for losses when runs occur off the equilibrium path. Martin (2006) shows how a central bank can provide liquidity as a lender of last resort to prevent runs without incurring moral hazard that deposit insurance induces. Ashcraft, McAndrews and Skeie (2011) and Freixas, Martin and Skeie (2011) presents theoretical and empirical evidence that central bank liquidity provision can reduce interbank liquidity stress in short-term funding markets as during the financial crisis. 
away from 0, i.e., if the valuation of collateral by less sophisticated investors can get very low in times of stress, then Proposition 9 shows that it may be optimal to restrict the extent of maturity transformation in the system, for example by reducing short-term borrowing and requiring that $\sum_{i} b_{i}<N$.

\section{Conclusion}

We have studied a model of short-term collateralized borrowing and the conditions under which runs can occur. The framework resembles the infinitehorizon bank model studied in Qi (1994), but extends that model beyond the pure theory of commercial banking and by considering profit-maximizing borrowers who do not make zero profits by assumption. We argue that borrowers must have an incentive to invest in securities on behalf of investors and show that under this constraint, borrowers will make profits that can be mobilized to forestall runs.

A key difference between traditional banks and modern financial intermediaries is that the former mainly hold opaque assets while the latter's assets are much more liquid and marketable. The value of collateral and the liquidity of asset markets therefore become crucial for the liquidity of intermediaries. Runs can be forestalled by mobilizing sufficient liquidity through asset sales and having sufficiently valuable collateral. This gives rise to two constraints that can be interpreted as an emergency liquidation constraint and a collateral constraint. Part of a borrower's liquidity comes directly from his steady state cash flow and part from the ability to liquidate illiquid assets.

We show that sales or purchases of assets affect the borrower's liquidity in steady state and in case of emergency. In steady state, selling assets ("securitization") generates liquidity today, but reduces the amount of assets held by the borrower. The net effect is to reduce the liquidity of the borrower in each period in steady state. Indeed, because of discounting, the price at which assets are sold today is smaller than the liquidity generated by an equal amount of securities maturing today. We show, in particular, that a run on a single borrower cannot happen if all borrowers have zero net purchases of assets in steady states. In contrast, a run can happen and bankrupt a borrower if the borrower undertakes sufficiently large net sales of assets in 
steady state.

Empirically, our comparative statics results are consistent with the findings by Schroth, Suarez, and Taylor (2012) who calibrate a dynamic run model to data from the 2007 run on ABCP conduits in the US. During the period from August to October 2007, the proportion of such conduits that had more than 10 percent of their paper maturing and did not re-issue new paper (i.e., had large outflow but no inflow of funds) rose from less than 5 percent to 35 percent. Schroth, Suarez, and Taylor (2012) find that the calibrated likelihood of such a run for individual conduits is highly sensitive to its short-term leverage, asset liquidity, and balance sheet strength. The result on short-term leverage and balance sheet strength is consistent with the effect of our two key variables $b_{i}$ and $L_{i}$ in the emergency liquidation constraint (40). Asset liquidity has no counterpart in our single-borrower run scenario, because we assume perfect asset markets there. However, to the extent that the ABCP market was in a systemic collapse since October 2007, our analysis of Section 5 suggests that the collapse of collateral values $\gamma_{i}^{t}$ was decisive, which corresponds to Schroth et al.'s variable $\alpha$ of asset liquidity.

In the light of our results it seems useful to augment Brunnermeier and Pedersen's (2009) distinction between market liquidity and funding liquidity by the notion of "balance sheet liquidity." If balance sheet liquidity is sufficient, the borrower either has enough liquidity in steady state or a well functioning secondary market provides the necessary emergency liquidity if the run is not systemic. Only if his balance sheet liquidity is insufficient, either because of too heavy short-term borrowing or too much securitization, will an individual run bring down the borrower. This resembles the purchase of Bear Stearns' assets by JP Morgan Chase in March 2008. However, in a systemic run, all borrowers become distressed and try to sell assets, which leads to market collapse. In such a case, the provision of massive amounts of liquidity by a "buyer of last resort" is the only remedy ex post. This resembles the market collapse after Lehman's failure in September 2008 and the substantial provision of liquidity by the Federal Reserve, notably through the PDCF. 


\section{Appendix: Proof of Proposition 1}

Proof. We first provide a partial characterization of steady states with positive profits, and then verify that they exist.

A) Suppose there is a steady state with $\pi_{k}>0$ and $b_{k}>0$ for at least one borrower $k$. The characterization proceeds in several steps.

1. $r_{i}=r_{j}$ for all borrowers $i, j$ with $b_{i}, b_{j}>0$.

Proof: Suppose that $r_{i}<r_{j}$ for some $i, j$ with $b_{i}, b_{j}>0$. Let $\mathcal{J}_{i}$ be the set of all borrowers $k$ with $r_{k}>r_{i}$ and $b_{k}>0 . \mathcal{J}_{i}$ is not empty because $j \in \mathcal{J}_{i}$. All $k \in \mathcal{J}_{i}$ must be saturated, i.e., have $b_{k}=Q_{k}$ (otherwise investors from $i$ would deviate). Hence, any borrower $k \in \mathcal{J}_{i}$ can deviate to $r_{k}-\varepsilon$ for $0<\varepsilon<r_{k}-r_{i}$ and strictly increase his profit.

This step states that competition forces all borrowers to pay the same rate of interest.

2. The steady-state interest rate satisfies

$$
(1-\alpha) \beta^{2} r^{2}+\alpha \beta r=1
$$

Proof: Consider the borrower $k$ with $\pi_{k}>0$ and $b_{k}>0$ who exists by assumption. For each unit of cash that $k$ receives and invests at date $t$, he pays back $\alpha r$ in $t+1$, generates returns $R_{k}$ in $t+2$, and pays back $(1-\alpha) r^{2}$ in $t+2$. Hence, his discounted profits on this one unit are $\beta^{2}\left(R_{k}-(1-\right.$ $\left.\alpha) r^{2}\right)-\beta \alpha r$. Alternatively he could invest his own cash. The discounted profits from not using the one unit of outside funds and rather investing his own money is $\beta^{2} R_{k}-1$. Since he receives funds from investors in steady state $\left(b_{k}>0\right)$ and has funds of his own $\left(\pi_{k}>0\right)$, this cannot be strictly better, which implies $(1-\alpha) \beta^{2} r^{2}+\alpha \beta r \leq 1$.

Suppose that this inequality is strict. For an arbitrary borrower $i$, this means that

$$
\beta^{2}\left(R_{i}-(1-\alpha) r^{2}\right)-\beta \alpha r>\beta^{2} R_{i}-1
$$

which is strictly positive by (3). Hence, all borrowers make strictly positive marginal profits from borrowing and investing and strictly prefer to use borrowed funds for investment rather than internal funds. Therefore, the total demand for funds is at least $\sum_{i} \bar{I}_{i}$. By (4) this implies that the market for borrowed funds cannot clear at $r$. 
This step compares the return of a borrower investing its own funds, which we can think of as internal finance, with the return on investing customer funds, which we can think of as external finance. The two returns must be equal in equilibrium. Note that (48) is solved by $\bar{r}=1 / \beta$.

3. If $\pi_{i}>0, I_{i}=\overline{I_{i}}$.

Proof: Suppose that $I_{i}<\overline{I_{i}}$ for one $i$. $i$ can increase his investment slightly at any date $t$ using his own cash. By condition (3), this yields a strict increase in discounted profits.

Note that this step requires internal liquidity to be available. Intuitively, it is then profitable to invest until the investment level reaches $\overline{I_{i}}$.

4. Total steady-state funding by investors is maximal: $\sum_{i=1}^{M} b_{i}=N$.

Proof: Because $r>1$ by (48), the total supply of funds is inelastically equal to $N$ in each period. Suppose that $\sum_{i=1}^{M} b_{i}<N$. This implies $Q_{i}=b_{i}$ for all $i$ (otherwise, investors would lend more to at least one borrower). Consider any borrower $i$ with $b_{i}>0$. He can strictly increase his profits by offering $r_{i}=r-\varepsilon$ for $\varepsilon>0$ sufficiently small, because he will not lose any investors.

5. If $\pi_{i}>0$ for all $i$, then $p_{j}=\beta R_{j}$ for all $j$.

Proof: If $\pi_{i}>0$ for all $i$, then current and future financial gains and losses from trading asset $j$ must be equalized at the margin.

B) Existence.

Take any allocation described in Proposition 1. As shown in A2 above, with $r=1 / \beta$ all borrowers make strictly positive discounted profits on each marginal dollar borrowed and invested and are indifferent between borrowing and using internal funds. They therefore find it indeed optimal to borrow any positive amount $b_{i}$. Because $\bar{r}>1$ and all borrowers pay the same interest rate, patient middle-aged investors find it indeed optimal to roll over their funding and young investors find it optimal to invest all their endowment. The bounds (9) and market clearing $\left(\sum_{i} b_{i}=N\right)$ are consistent with (4) because of (3).

In the allocations described in Proposition 1, steady-state per-period profits are

$$
\pi_{i}=\left(R_{i}-1\right) I_{i}-(1-\beta) R_{i} A_{i}+(1-\beta) \sum_{j} R_{j} A_{i j}-\frac{1}{\beta^{2}}\left(1-\alpha+\alpha \beta-\beta^{2}\right) b_{i}
$$


If $A_{i j}=0$ for all $i, j$ (no asset sales), then (9) implies that

$$
\pi_{i} \geq\left(\beta^{2} R_{i}-1\right) I_{i}>0
$$

Since all profits are strictly positive, there is a set $S \subset \mathbb{R}_{+}^{M^{2}}$ with $0 \in S$ such that for all $\left(A_{i j}\right)_{i, j=1, \ldots, M} \in S$ we have $\pi_{i}>0$. Hence, the allocations of Proposition 1 are consistent with strictly positive steady-state profits if $\left(A_{i j}\right)_{i, j=1, \ldots, M} \in S$. By A3 above, investment then is maximal.

The first inequality in (10) is equivalent to the repayment condition (5), evaluated at the equilibrium values. For the second inequality in (10), note that in steady state the borrower has $\bar{I}_{i}$ units of fresh and $\bar{I}_{i}$ units of seasoned collateral to offer. This total of $2 \bar{I}_{i}$ units of collateral can be pledged for the total amount of funds provided by investors per period, which is $b_{i}[1+(1-\alpha) \bar{r}]=b_{i}[1-\alpha+\beta] / \beta$. It follows that the maximum amount of collateral per unit that the borrower can offer is

$$
\kappa_{i} \equiv \frac{2 \beta \bar{I}_{i}}{b_{i}[1-\alpha+\beta]} .
$$

The second inequality in (10) is the condition $k_{i} \leq \kappa_{i}$. Both inequalities in (10) are compatible because of (9).

Asset sales $A_{i}$ cannot exceed the borrower's assets net of what he has pledged as collateral. In equilibrium he pledges $((1-\alpha) \bar{r}+1) b_{i} k_{i} / 2$ units of seasoned collateral, which implies the right hand side of (11). This right hand side is non-negative by (10). The right-hand side of (12) is strictly positive by (9) and (3). 


\section{References}

[1] Acharya, V., Gale, D.and Yorulmazer, T., 2011. Rollover Risk and Market Freezes. Journal of Finance 66, 1177-1209.

[2] Acharya, V., Shin, H., Yorulmazer,T., 2011. Crisis Resolution and Bank Liquidity. Review of Financial Studies 24, 2166-2205.

[3] Acharya, V., Schnabl, P., Suarez, G., 2013. Securitization without Risk Transfer. Journal of Financial Economics 107, 515-536.

[4] Allen, F., Gale, D., 1994. Limited Market Participation and Volatility of Asset Prices. American Economic Review 84, 933-955.

[5] Allen, F., Gale, D., 1998. Optimal Financial Crises. The Journal of Finance 53, 1245-1284.

[6] Allen, F., Gale, D., 2004a. Financial Fragility, Liquidity, and Asset Prices. Journal of the European Economic Association 2, 1015-1048.

[7] Allen. F., Gale, D., 2004b. Financial Intermediaries and Markets. Econometrica 72, 1023-61.

[8] Allen, F., Gale, D., 2007. Understanding Financial Crises, Oxford and New York.

[9] Ashcraft, A., McAndrews, J., Skeie, D., 2011. Precautionary Reserves and the Interbank Market. Journal of Money, Credit, and Banking 43, 311-348.

[10] Bolton, P., Santos, T., Scheinkman, J., 2011. Outside and Inside Liquidity. Quarterly Journal of Economics 126-1, 259-321.

[11] Brunnermeier, M. K., Pedersen, L. H., 2009. Market Liquidity and Funding Liquidity. Review of Financial Studies 22, 2201-2238.

[12] DeMarzo, P., 2005. The Pooling and Tranching of Securities: A Model of Informed Intermediation. Review of Financial Studies 18, 1-35. 
[13] Diamond, D., 1997. Liquidity, Banks, and Markets. Journal of Political Economy 105, 928-56.

[14] Diamond, D., P. Dybvig, 1983. Bank Runs, Deposit Insurance, and Liquidity. Journal of Political Economy 91, 401-419.

[15] Fecht, F., 2004. On the Stability of Different Financial Systems. Journal of the European Economic Association 2, 969-1014.

[16] Freixas, X., Martin, A., Skeie, D., 2011. Bank Liquidity, Interbank Markets and Monetary Policy. Review of Financial Studies 24, 2656-2692.

[17] Gennaioli, N., Shleifer, A., Vishny, R., 2012. Neglected Risks, Financial Innovation, and Financial Fragility. Journal of Financial Economics 104, 452-468.

[18] Gorton, G., Huang, L., 2004. Liquidity, Efficiency, and Bank Bailouts. American Economic Review 94, 455-483.

[19] Gorton, G., Metrick, A., 2012. Securitized Banking and the Run on Repo. Journal of Financial Economics 104, 425-451.

[20] Hart, O., Moore, J., 1998. Default and Renegotiation: A Dynamic Model of Debt. Quarterly Journal of Economics 113, 1-41.

[21] He, Z., Xiong, V., 2012. Dynamic Debt Runs. Review of Financial Studies 25, 1799-1843.

[22] Kahneman, D., 2011.Thinking, Fast and Slow. London and New York.

[23] Kiyotaki, N., Moore, J. H., 1997. Credit Cycles. Journal of Political Economy 105, 211-248.

[24] Martin A., 2006. Liquidity provision vs. deposit insurance: preventing bank panics without moral hazard. Economic Theory 28, 197-211.

[25] Martin A., Parigi, B., 2013. Bank Capital Regulation and Structured Finance. Journal of Money, Credit, and Banking 45, 87-119. 
[26] Martin A., Skeie, D., von Thadden, E., 2014. Repo Runs. Review of Financial Studies, forthcoming..

[27] Parlour, C., Plantin, G., 2007. Loan Sales and Relationship Banking. The Journal of Finance 63, 1291-1314.

[28] Postlewaite, A., Vives, X., 1986. Bank Runs as an Equilibrium Phenomenon. Journal of Political Economy 95, 485-91.

[29] Pozsar, Z., Adrian, T., Ashcraft, A., Boesky, H., 2010. Shadow Banking. Working Paper, Federal Reserve Bank of New York.

[30] Qi. J., 1994. Bank Liquidity and Stability in an Overlapping Generations Model. Review of Financial Studies 7, 389-417.

[31] Schroth, E., Suarez, G., Taylor, L., 2012. Dynamic Debt Runs and Financial Fragility: Evidence from the 2007 ABCP Crisis. manuscript

[32] Segura, A., Suarez, J., 2012. Dynamic Maturity Transformation, manuscript CEMFI, Madrid.

[33] Skeie, D., 2008. Banking with Nominal Deposits and Inside Money. Journal of Financial Intermediation 17, 562-584.

[34] Uhlig, H., 2010. "Crises in Repo Markets with Adverse Selection." Manuscript, University of Chicago.

[35] von Thadden, E., Berglöf, E., Roland, G., 2010. The Design of Corporate Debt Structure and Bankruptcy. Review of Financial Studies 23, 26482679 . 